\section{Use of 1,3-Dichloropropene to Reduce Irrigation Requirements of Sting Nematode-infested Bermudagrass}

\author{
Laurie E. Trenholm ${ }^{1}$ \\ Environmental Horticulture Department, Gainesville, FL 32611
}

Darin W. Lickfeldt
Dow AgroSciences, Indianapolis, IN 46268

William T. Crow
Entomology and Nematology Department, University of Florida, Gainesville,
FL 32611

Additional index words. curfew, deficit irrigation, drought survival

\begin{abstract}
This research was conducted to determine if application of 1,3-dichloropropene $(1,3-D)$ could reduce turfgrass water requirements in soil infested with sting nematodes (Belonolaimus longicaudatus Rau). The effects of 1,3-D and fenamiphos were evaluated on quality and persistence of 'Tifway 419' bermudagrass (Cynodon dactylon $\times$ C. transvaalensis Burtt-Davy) subjected to drought or deficit irrigation. The research consisted of two greenhouse studies in 2002 and 2003 where irrigation was either withheld or applied in deficit quantities, and one field study in 2003 where irrigation was withheld. In general, 1,3-D-treated turf maintained up to $\mathbf{4 0} \%$ higher quality during drought than other treatments and had up to $27 \%$ less leaf wilting. As drought severity increased, 1,3-D treatments had better spectral reflectance values, indicating better physiological functioning under stress. Results of this research suggest that application of 1,3-D in sting nematode-infested soils may increase bermudagrass drought survival.
\end{abstract}

Water use by turfgrass is under increasing scrutiny amid concerns regarding this limited natural resource. A 1995 U.S. GolfAssociation (USGA) water resource investigation estimated that an average Florida golf course irrigated 89 acres with 205,000 gal water each day (USGA, 1999). With over 1500 golf courses in Florida, a reduction in water use could save billions of gallons of water each year. Both golf courses and residential lawns are often alleged to waste water in an effort to maintain optimal quality. Water conservation efforts on golf courses might include use of nonpotable water, reduced irrigation of fairways and roughs, use of soil amendments to enhance soil water holding capacity, or use of chemicals to promote maximum stress tolerance in turf.

Few pest control products or plant growth regulators have been associated with improved turfgrass drought tolerance or avoidance. Ervin and Koski (2001) found limited instances of reduced evapotranspiration (ET) in kentucky bluegrass (Poa pratensis L.) treated with plant growth regulator trinexapac-ethyl [4-(cyclopropyl-hydroxy-methylene)-3,5-dioxo-cyclohexane-carboxylic acid ethylester] over a 3-yr period. Other research has shown a reduction in ET following treatment with trinexapac-ethyl

Received for publication 28 Sept. 2004. Accepted for publication 19 Nov. 2004. Florida Agricultural Experiment Station Journal Series. The authors would like to thank Dow AgroSciences LLC for financial support of this research. Mention of a product or vendor does not imply endorsement by the University of Florida.

${ }^{1}$ To whom reprints should be addressed: ltrenholm@ifas.ufl.edu.
(Marcum and Jiang, 1997). Products containing humic acid or seaweed extract were associated with enhanced drought tolerance in tall fescue (Festuca arundinacea Schreb.) and creeping bentgrass (Agrostis palustris Huds. A.) (Zhang and Schmidt, 2000).

Reduced water use or drought avoidance may also be attributed to turfgrass anatomical or morphological features. Increased root mass has been shown to maintain sufficient turfgrass quality when water resources are limiting (Ervin and Koski, 1998) and deep rooting ability is considered to be a primary mechanism of drought survival in plants (Levitt, 1980). Marcum et al. (1995) attributed greater rooting depth, mass, and branching at lower depths to enhanced drought resistance in zoysiagrass (Zoysia spp.).

Sting nematode is a destructive pathogen of bermudagrass and other turfgrass species. This plant-parasitic nematode is common in sandy soils in the southeastern U.S. and will greatly reduce bermudagrass root systems Perry and Rhoades, 1982), thereby enhancing susceptibility to drought stress. In sting nematode-infested sites, effective nematicides may enhance drought tolerance of turf and reduce the need for more frequent irrigation.

The fumigant nematicide, 1,3-dichloropropene (1,3-D), has been used as a preplant treatment for many years. Research has shown this to be a very effective treatment for control of sting nematodes and improvement of root systems in sting nematode-infested soil (Crow, 2002; Crow et al., 2003). The nematicide is injected into established turf at 12.7 to 15.25 (Giblin-Davis et al., 1992; Johnson, 1970; cm deep using tractor-mounted slit-injection equipment. It is applied as a liquid at $47 \mathrm{~L} \cdot \mathrm{ha}^{-1}$ and then vaporizes upward through the rootzone, killing nematodes upon contact.

The objective of these experiments was to determine if injection of 1,3-D into nematodeinfested bermudagrass turf under golf course fairway conditions increased drought tolerance of bermudagrass turf during periods of no or reduced irrigation.

\section{Materials and Methods}

Greenhouse studies. Two greenhouse studies were initiated in April 2002. One was a drydown study where no irrigation was applied until severe wilt occurred; the other applied deficit rates of irrigation over time. Three treatments were applied in these studies: 1) untreated control, 2) 1,3-D, and 3) the organophosphate nematicide fenamiphos (Nemacur 10G). 'Tifway 419' bermudagrass was harvested from an established stand at the G.C. Horn Turfgrass Field Laboratory in Gainesville, Fla. Root-free stolons were planted into10-cm-diameter $\times 46$-cm-high polyvinyl chloride (PVC) lysimeters in early spring and allowed to establish until uniform cover was reached. Soil used was an Arredondo fine sand from the A horizon (loamy, silicious, hyperthermic Grossarenic Paleudult). Lysimeters were inoculated with 100 sting nematodes per lysimeter in mid-May 2002 and chemical treatments were applied in late July. 1,3-D was applied at $55 \mathrm{~kg} \cdot \mathrm{ha}^{-1}$ a.i. by pipetting into a 5 $\mathrm{mm}$-diameter $\times 14$-cm deep hole at the center of each lysimeter. Immediately after treatment, the holes were pinched closed and $105 \mathrm{ml}$ of water was added to each lysimeter to seal in the fumigant. Fenamiphos was applied topically at the rate of $11.2 \mathrm{~kg} \cdot \mathrm{ha}^{-1}$ a.i. and irrigated in with $105 \mathrm{~mL}$ of water. Untreated controls received $105 \mathrm{~mL}$ of water only. Drought treatments were initiated in late December 2002. Turf was fertilized with nitrogen $(\mathrm{N})$ at $1.25 \mathrm{~g} \cdot \mathrm{m}^{-2}$ every other week and irrigated as needed before initiation of drought treatments.

In the drydown study, pots were irrigated to field capacity on 24 Dec. 2002 and irrigation was then withheld until $50 \%$ wilt was seen on most of the samples. The grass was allowed to recover and the study was repeated beginning 13 Feb. 2003. Lysimeters were arranged in a completely randomized design with four replications.

In the deficit irrigation study, irrigation treatments began on 2 Jan. 2003 and continued until 16 Apr. 2003. Irrigation treatments were applied twice weekly based on gravimetric measurement of lysimeters. Lysimeters were weighed before application of water, irrigated to field capacity, and then reweighed. This was considered $100 \%$ evapotranspiration (ET). Deficit irrigation was then determined as $67 \%$ and $33 \%$ of this measure, respectively. Experimental design was a randomized complete block design with three replications.

Evaluations for both studies included visual scores for turfgrass quality, color, leaf firing, and leaf folding. Quality and color ratings were taken on a scale from 1 to 9 , 
with 9 representing optimal green turf and 1 representing dead turf. Leaf firing and folding were evaluated on a percentage basis of leaf chlorosis and number of leaf blades per pot that had folded, respectively. Soil moisture content was taken with a time domain reflectometer (TDR) (IMKO Micromodultechnik GmbH; Ettlingen, Germany). Multispectral reflectance measurements were taken with a Cropscan Model MSR16 (Cropscan Inc., Rochester, Minn.) on the deficit irrigation study only. The spectrometer was fitted with filters to measure reflectance at 450, 550, 660, 694, 710, 760, 810, and $930 \mathrm{~nm}$. In addition, the following growth and stress indices were evaluated:

NDVI (normalized difference vegetation index) growth index computed as $\mathrm{R}_{930}-\mathrm{R}_{660} / \mathrm{R}_{930}$
$+\mathrm{R}_{660}$. Best $=$ highest value.

IR/R (leaf area index) growth index computed as $R_{930} / R_{660}$. Best $=$ highest value.

Stress 1 index computed as $\mathrm{R}_{710} / \mathrm{R}_{760}$. Best $=$ lowest value.

Stress 2 index computed as $R_{71} 0 / R_{810}$. Best $=$ lowest value.

Field study. Two fairways were selected on the Tierra Del Sol GolfCourse at The Villages, Lady Lake, Fla. Both sites were infested with damaging populations of sting nematodes. 1,3-D was injected into $30.5 \mathrm{~m}$ long $\times 2 \mathrm{~m}$ diameter plots on both fairways on 9 May 2003. The injection was conducted by Southern Soils Turf Management (Lake Mary, Fla.) using a coulter, knife, and roller assembly, which are regularly used for commercial applications.

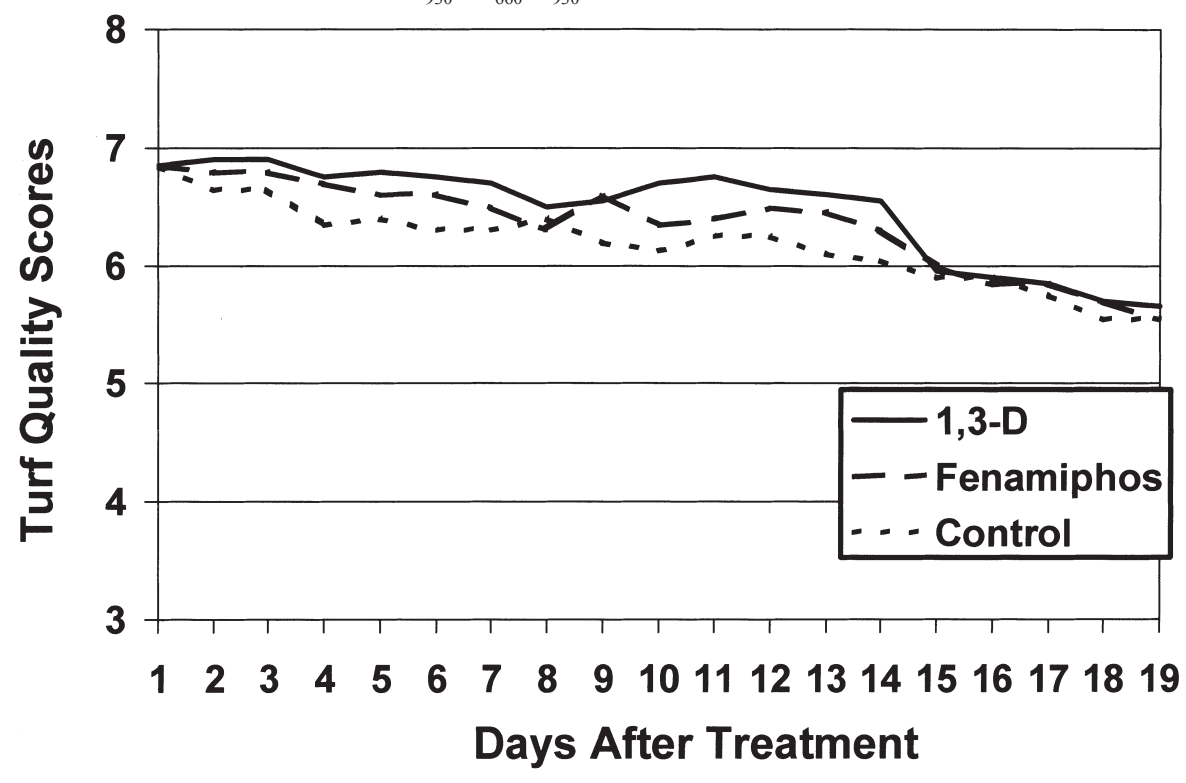

Fig. 1. Turf quality in response to treatment during drydown 1 in a greenhouse study. Turf quality scores based on a scale from 1 to 9 , where $9=$ best score.

Fig. 2. Turf quality in response to treatments during drydown 2 in a greenhouse study. Turf quality scores based on a scale from 1 to 9 , where $9=$ best score.

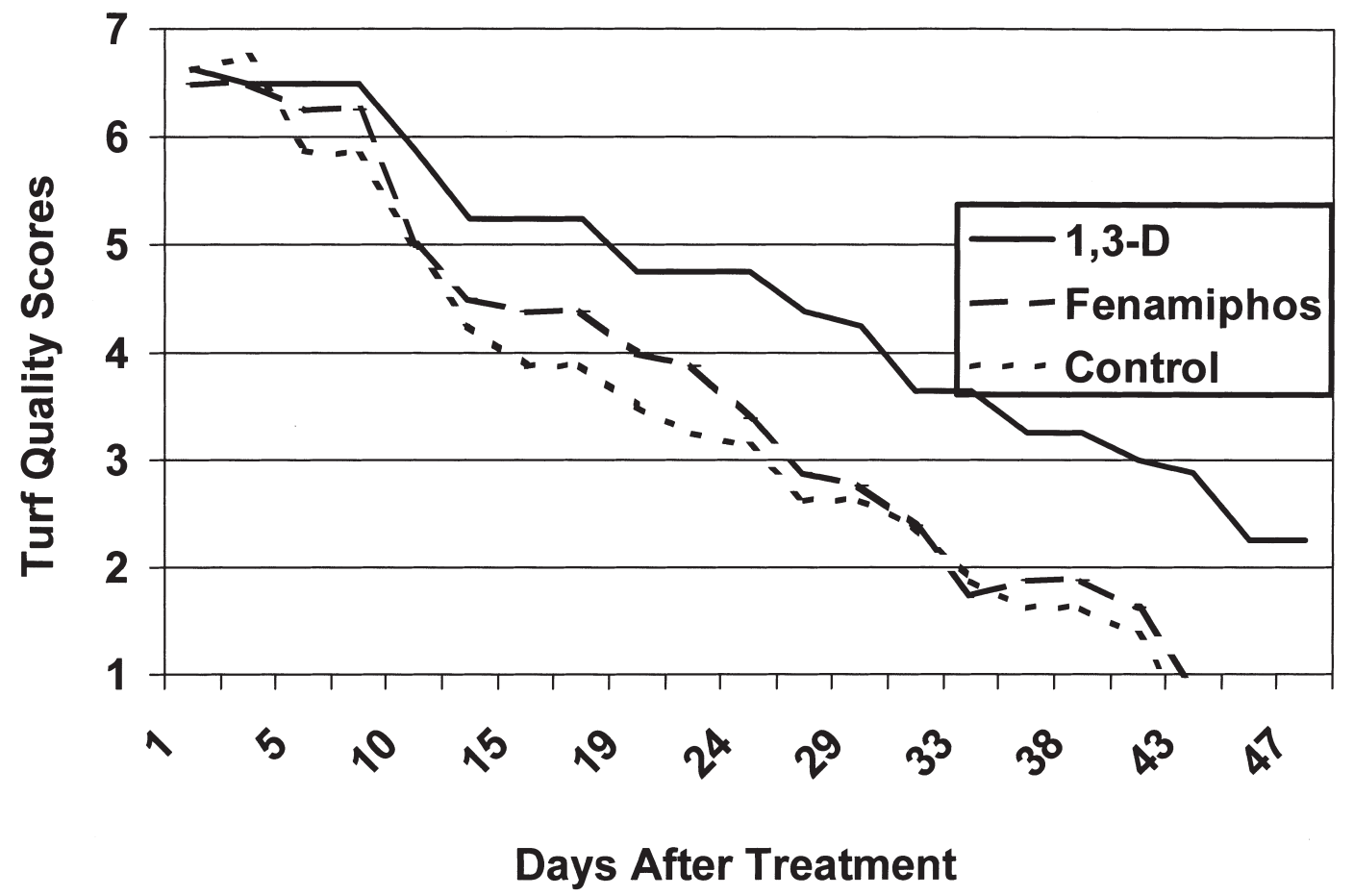

HortScience Vol. 40(5) August 2005 
As per label recommendations, all plots were irrigated with $1.2 \mathrm{~cm}$ of water within $30 \mathrm{~min}$ of injection. Conditions were dry and clear at time of application.

Drought treatments were initiated on 24 June 2003. There was no rainfall during the evaluation period at this location. Nematode assays were conducted before treatment and again before initiation of drought by the University of Florida Nematode Assay Lab, Gainesville. Ten 2.5-cm-diameter root cores per plot were pulled on 23 June 2003. Roots were washed free of soil, dried to constant weight, and weighed.

Evaluations were taken weekly or more frequently until the experiment was terminated on 16 July 2003. Visual quality, color, leaf firing, and leaf folding scores were taken as described above. Soil moisture content and reflectance measurements were also taken as previously described.

The experiment was replicated four times on each fairway using a completely randomized design. Data presented were averaged over both fairways due to uniform turf responses. For all studies, data were analyzed using SAS (SAS Institute, Cary, N.C.). Analysis of variance was used to determine differences to treatments at the 0.05 probability level and the Waller-Duncan $\mathrm{k}$ ratio $t$ test was used to separate differences between means.

\section{Results and Discussion}

Drydown study. There were no differences in visual turf quality during drydown 1 (Fig. 1). At $16 \mathrm{~d}$ after treatment (DAT), all treatments had visual quality below the minimally acceptable score of 6 . In contrast, during drydown 2 , turf treated with 1,3-D maintained better quality from 6 DAT until the experiment was terminated (Fig. 2). Untreated turf quality was below 6 at 5 DAT, while 1,3-D and fenamiphos treatments both showed acceptable quality up to 10 DAT. Averaged from 10 to 47 DAT, 1,3$\mathrm{D}$ treated turf maintained $40 \%$ higher quality

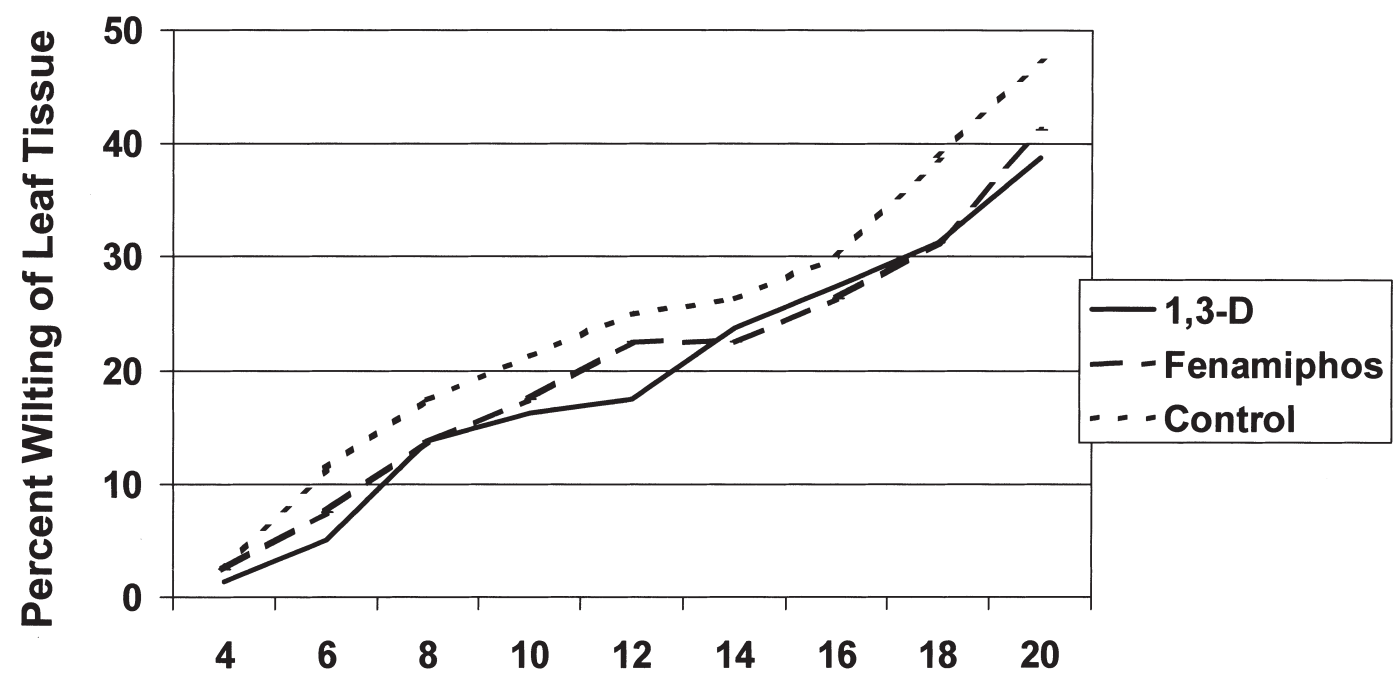

Days After Treatment

Fig. 3. Percent wilting of leaf tissue in response to treatments during drydown 1 in a greenhouse study.

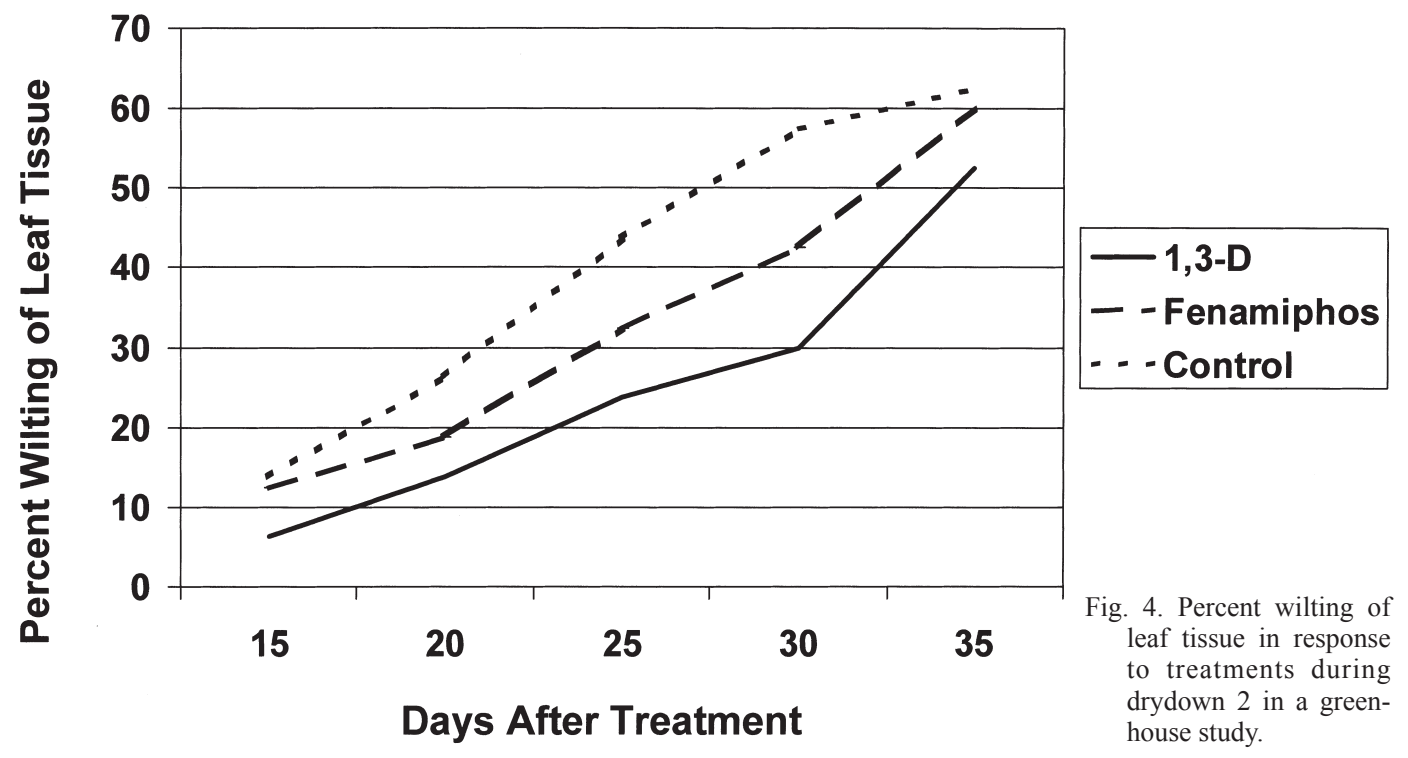


than nontreated turf and 30\% higher quality than fenamiphos treatments.

During drydown 1, untreated turf averaged $6 \%$ and $20 \%$ more wilt than fenamiphos and 1,3-D treated turf, respectively, over the course of the experiment (Fig. 3). During drydown 2, where differences occurred, 1,3$\mathrm{D}$ treated turf had less wilt than nontreated turf (Fig. 4). Averaged over the duration of the experiment, untreated turf showed 14 and $27 \%$ more wilt than fenamiphos or $1,3-\mathrm{D}$ treatments, respectively. Leaf firing did not differ between treatments during drydown 1, but 1,3-D treatments had less leaf firing ( $42 \%$ and $49 \%$ less than fenamiphos treatments and controls, respectively) from day 22 through 50 in drydown 2 (Fig. 5). Since leaf firing is often considered a mechanism of drought resistance (Huang et al., 1997), this suggests that 1,3-D treatments were under less drought stress than other treatments.

Deficit irrigation study. Turf visual quality was higher in 1,3-D treated pots from 9 weeks after treatment (WAT) through the termination of the study (Fig. 6). Averaged over this time period, 1,3-D treated turf had

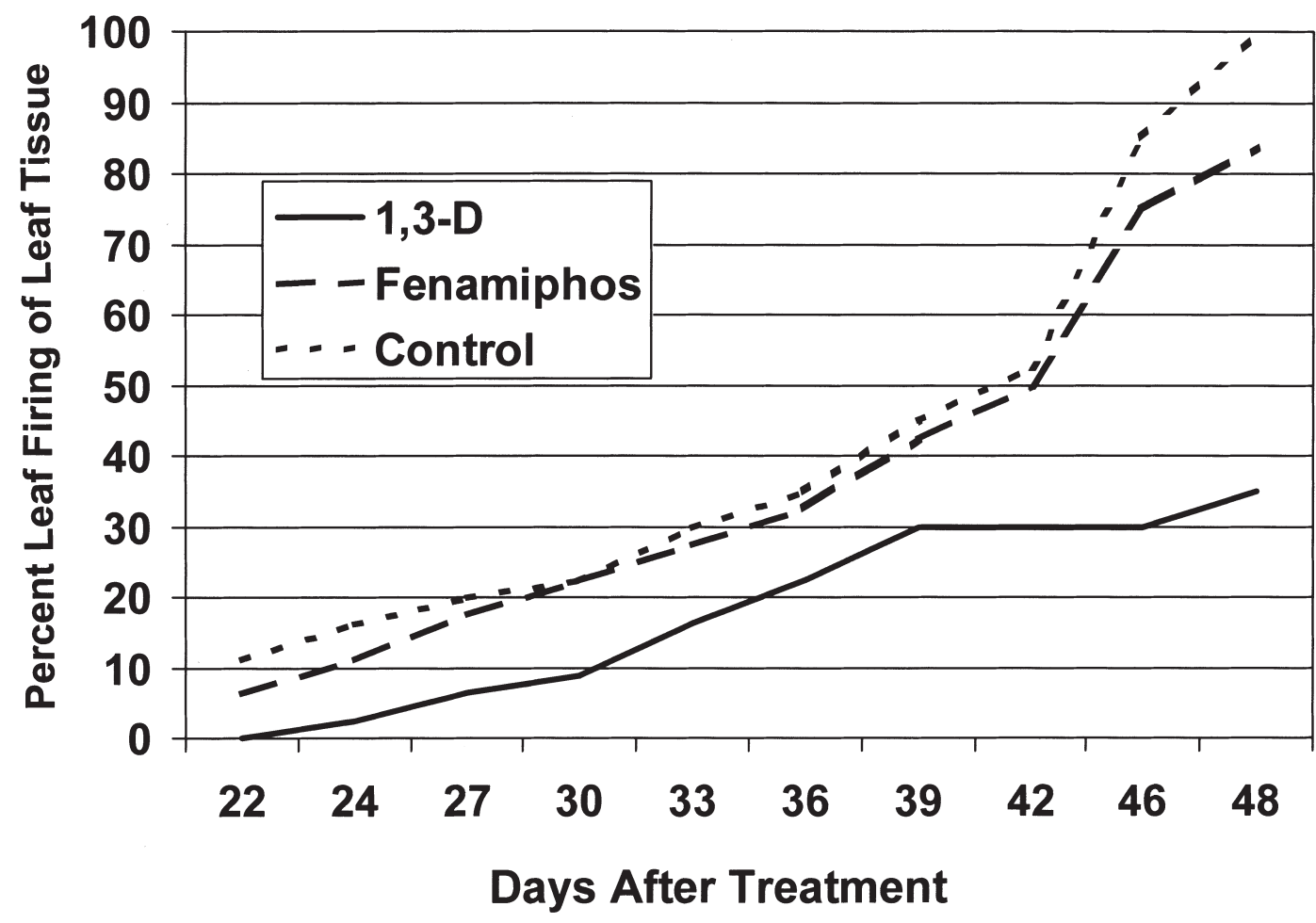

Fig. 5. Percent leaf firing of tissue in response to treatments during drydown 2 in a greenhouse study. Firing scores based on percentage of chlorotic tissue at leaf tips.

Fig. 6. Turf quality in response to treatments under deficit irrigation in a greenhouse study. Turf quality scores based on a scale from 1 to 9 , where $9=$ best score.

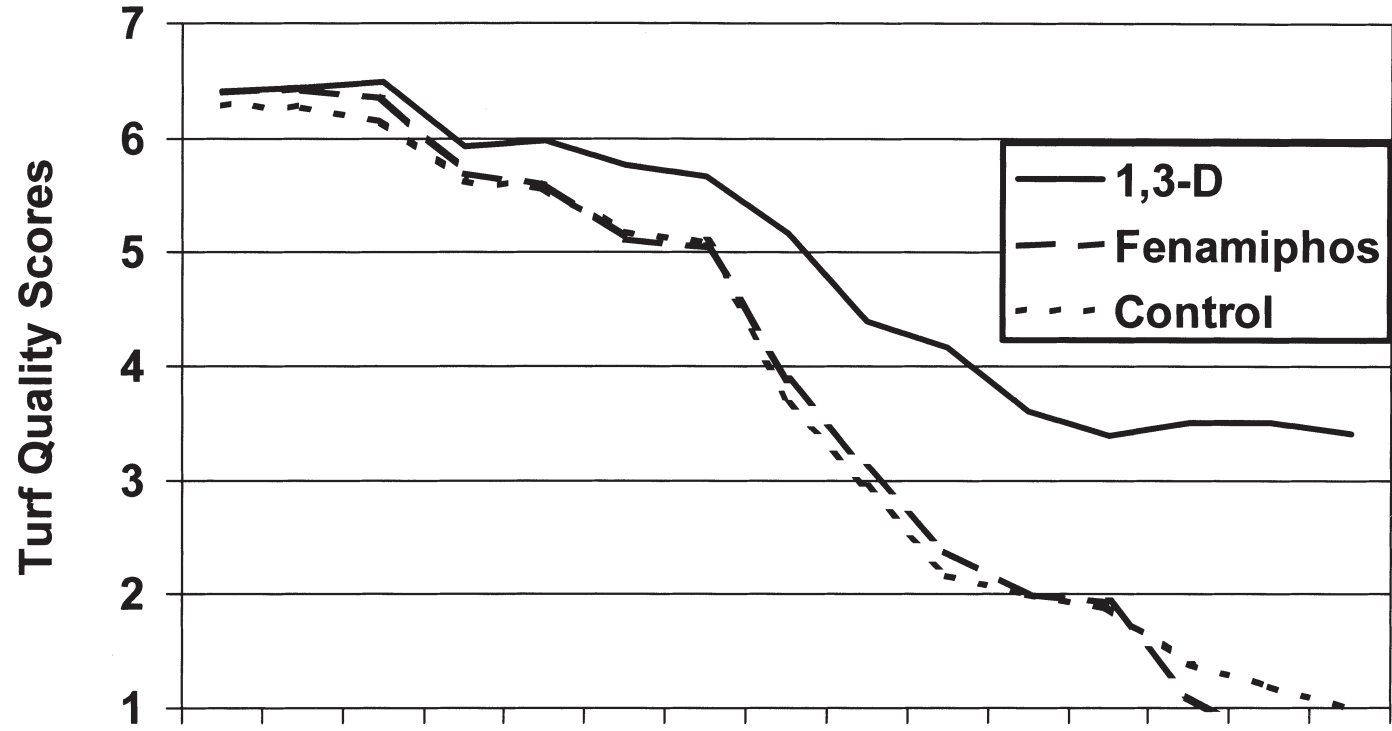

$\begin{array}{lllllllllllllll}2 & 3 & 4 & 5 & 6 & 7 & 8 & 9 & 10 & 11 & 12 & 13 & 14 & 15 & 16\end{array}$ 


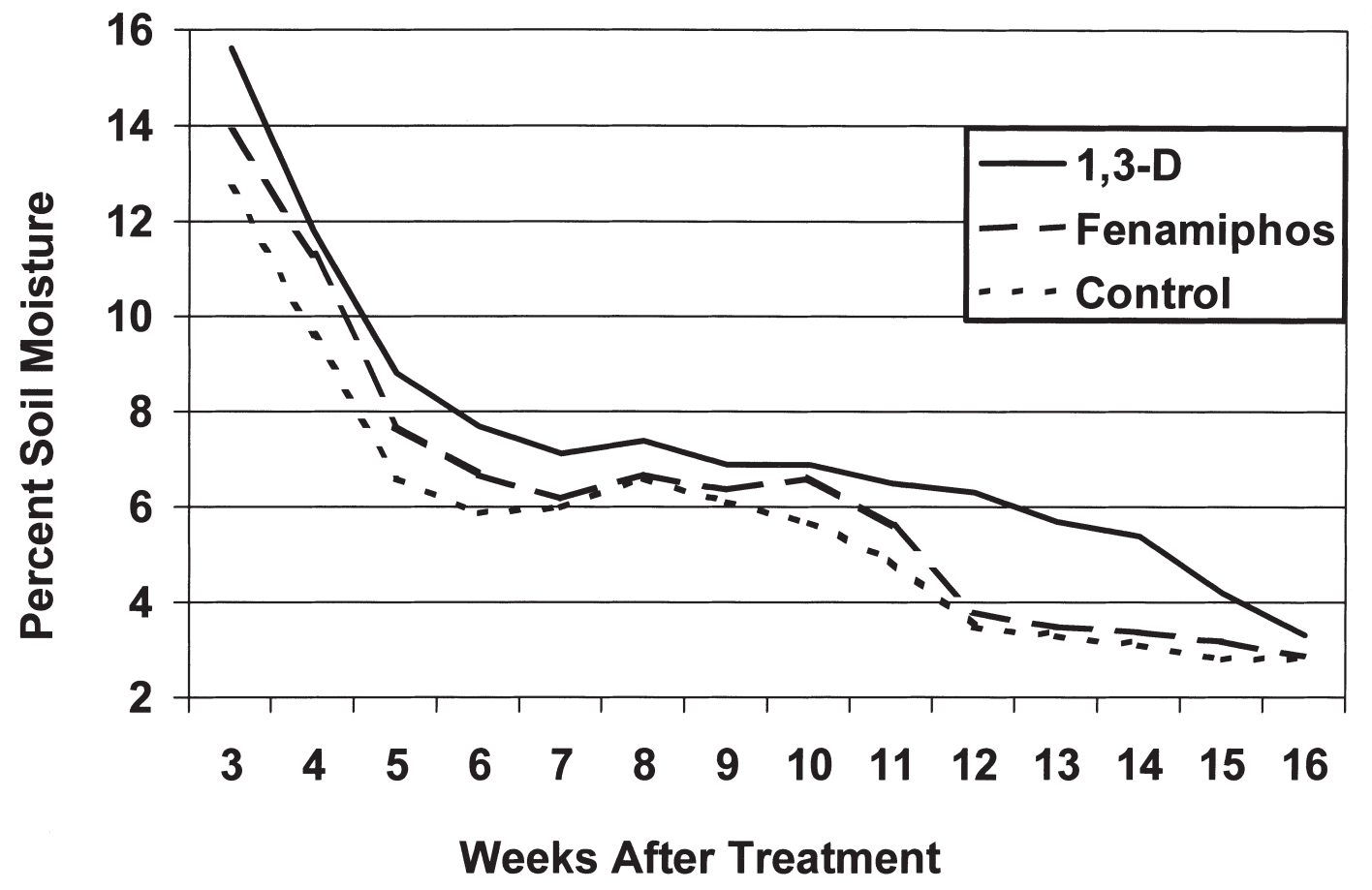

Fig. 7. Percent soil moisture in response to treatments under deficit irrigation in a greenhouse study.

Table 1. Reflectance values in response to treatments in greenhouse deficit irrigation study. Optimal values are in bold.

\begin{tabular}{|c|c|c|c|c|c|c|}
\hline \multirow[b]{2}{*}{ Treatment } & \multicolumn{6}{|c|}{ Parameter } \\
\hline & Wv 660 & Wv 694 & NDVI & LAI & Stress 1 & Stress 2 \\
\hline \multicolumn{7}{|l|}{ Week 8} \\
\hline Curfew & $2.0 \mathrm{a}^{2}$ & $2.5 \mathrm{a}$ & $0.84 a$ & $13.2 \mathrm{a}$ & $0.29 \mathrm{a}$ & $0.24 \mathrm{a}$ \\
\hline Nemacur & $3.7 \mathrm{~b}$ & $4.8 \mathrm{~b}$ & $0.75 \mathrm{~b}$ & $7.9 \mathrm{~b}$ & $0.36 \mathrm{a}$ & $0.29 \mathrm{a}$ \\
\hline Control & $2.5 \mathrm{ab}$ & $3.6 \mathrm{ab}$ & $0.80 \mathrm{ab}$ & $10.7 \mathrm{ab}$ & $0.35 \mathrm{a}$ & $0.27 \mathrm{a}$ \\
\hline$P$ value & 0.03 & 0.01 & 0.05 & 0.02 & NS & NS \\
\hline \multicolumn{7}{|l|}{ Week 10} \\
\hline Curfew & $2.2 \mathrm{a}$ & $2.7 \mathrm{a}$ & $0.78 \mathrm{a}$ & $8.3 \mathrm{a}$ & $0.37 \mathrm{a}$ & $0.33 \mathrm{a}$ \\
\hline Nemacur & $3.4 \mathrm{~b}$ & $4.7 \mathrm{~b}$ & $0.71 \mathrm{a}$ & $7.2 \mathrm{a}$ & $0.45 \mathrm{a}$ & $0.37 \mathrm{a}$ \\
\hline Control & $2.4 \mathrm{ab}$ & $3.1 \mathrm{ab}$ & $0.73 \mathrm{a}$ & $7.7 \mathrm{a}$ & $0.41 \mathrm{a}$ & $0.33 \mathrm{a}$ \\
\hline$P$ value & 0.04 & 0.05 & NS & NS & NS & NS \\
\hline \multicolumn{7}{|l|}{ Week 14} \\
\hline Curfew & $9.8 \mathrm{a}$ & $11.9 \mathrm{a}$ & $0.68 \mathrm{a}$ & $6.1 \mathrm{a}$ & $0.47 \mathrm{a}$ & $0.38 \mathrm{a}$ \\
\hline Nemacur & $10.4 \mathrm{a}$ & $12.1 \mathrm{a}$ & $0.43 \mathrm{~b}$ & $2.9 \mathrm{~b}$ & $0.84 \mathrm{~b}$ & $0.69 \mathrm{~b}$ \\
\hline Control & $8.8 \mathrm{a}$ & $9.5 \mathrm{a}$ & $0.42 \mathrm{~b}$ & $3.1 \mathrm{~b}$ & $0.86 \mathrm{~b}$ & $0.84 \mathrm{~b}$ \\
\hline$P$ value & NS & NS & 0.001 & 0.006 & 0.001 & 0.001 \\
\hline
\end{tabular}

${ }^{\mathrm{z}}$ Means followed by the same letter do not differ significantly at $P=0.05$.

$32 \%$ higher quality than the other treatments. No differences existed in turf quality between fenamiphos and control treatments during the treatment period.

Less leaf wilting occurred in 1,3-D treated turf than in other treatments from 4 to 10 WAT (data not shown). Similarly, less leaffiring was seen in 1,3-D treated turf from 4 to 16 WAT. As in the drydown study, this indicates less drought stress in 1,3-D treated turf.

Averaged over all irrigation treatments, soil moisture differed due to chemical treatment from 12 through 14 WAT (Fig. 7). From 12 to 14 WAT, 1,3-D treated pots maintained higher soil moisture than other treatments. In previous work, turf grown in lysimeters of this type exhibited severe drought stress symptoms when soil moisture dropped below $4 \%$ to $6 \%$ (Lee et al., unpublished data). These moisture levels were reached at about 12 WAT in control and fenamiphos treated turf and 15 WAT in 1,3-D treated turf. Again, this could indicate less drought stress and perhaps reduced ET resulting from 1,3-D application and also suggests that frequency of irrigation could be reduced following 1,3-D application without reaching critical soil moisture levels.

Multispectral reflectance was measured throughout the evaluation period (Table 1). By 8 WAT, differences due to chemical treatments were evident. Throughout the visual range, turf grown in 1,3-D treated pots maintained lower reflectance values, which indicates increased light absorption at these wavelengths. 1,3-D and control treatments ranked in the best statistical category at $694 \mathrm{~nm}$ and indices NDVI and LAI. This trend continued at 10 WAT at 660 and $694 \mathrm{~nm}$. By 14 WAT, under extreme drought stress, all indices suggest that 1,3-D treated pots performed better than other treatments. Previously, Fenstermaker-Shaulis et al. (1997) reported that NDVI could be reliably used to detect drought stress in tall fescue (Festuca arundinacea Schreb) and Trenholm et al. (2000) reported reliable detection of multiple stresses in turf with visible range reflectance values and indices used in this research. All reflectance measurements from these studies suggest that, as drought stress intensifies, 1,3-D treated pots were better able to regulate physiological functioning and light assimilation as measured by spectral reflectance.

Field study. Population densities of sting nematode were reduced $92 \%(P=0.02)$ and $74 \%(P=0.02)$ by $1,3-\mathrm{D}$ compared to untreated controls in the two trials, respectively. Turfgrass quality (Fig. 8) and color (data not shown) were better for 1,3-D treated plots on all rating dates. Average quality ranged from $20 \%$ to $28 \%$ higher and average color from $20 \%$ to $29 \%$ higher in 1,3-D treated plots as drought stress increased over time. Multispectral reflectance values likewise suggest that $1,3-\mathrm{D}$ treated turf performed better at all wavelengths measured (Figs. 9 and 10) on multiple evaluation dates. There were no differences in dry root weights between treated and nontreated turf, although Crow et al. (2003) had previously reported improved root production in sting nematodeinfested sites following 1,3-D application.

Results from these studies suggest that treatment with 1,3-D can alleviate or post- 
pone drought stress on sting nematode-infested sites when rain or irrigation water is limiting. Although we found no statistical differences in root weights between treatments in the field study, rooting depth was observed to be greater in 1,3-D treatments, allowing for enhanced water uptake from deeper in the soil due to reduced nematode damage to the root system. This could allow for reduced water usage following 1,3-D treatment.

\section{Literature Cited}

Crow, W.T., R.M. Giblin-Davis, and D.W. Lickfeldt. 2003. Slit-injection of 1,3-dichloropropene for management of Belonolaimus longicaudatus on established bermudagrass. J.Nematol. 35:302-305.

Crow, W.T. 2002. Nematode, where is thy sting? Golf Course Mgt. 70:103-106.

Ervin, E.H. and A.J. Koski. 2001. Trinexapac-ethyl effects on kentucky bluegrass evapotranspiration. Crop Sci. 41:247-250.

Ervin, E.H. and A.J. Koski.1998. Growth responses of Lolium perenne L. to trinexapac-ethyl. Hort Sci. 33(7):1200-1202.

Fenstermaker-Shaulis, L.K., A. Leskys, and D.A. Devitt. 1997. Utilization of remotely sensed data to map and evaluate turfgrass stress associated with drought. J. Turfgrass Mgt. 2:65-81.

Giblin-Davis, R.M., J.L. Cisar, F.G. Bilz, and K.E. Williams. 1992. Host status of different bermudagrasses (Cynodon spp.) for the sting nematode, Belonolaimus longicaudatus. Supplement to J. of Nematology 24:749-756.

Huang, B., R.R. Duncan, and R.N. Carrow. 1997. Drought-resistance of seven warm-season turfgrasses under surface soil drying: shoot response. Crop Sci. 37:1858-1863.

Johnson,A.W. 1970. Pathogenicity and interaction of three nematode species on six bermudagrasses. J. Nematol. 2:36-41.

Levitt, J. 1980. Responses of plants to environmental stresses. vol. 1. Chilling, freezing, and high temperature stresses. Academic Press, New York.

Marcum, K.B., M.C. Engelke, S.J. Morton, and R.H. White. 1995. Rooting characteristics and associated drought resistance of zoysiagrasses. Agron. J. 87:534-538.

Marcum, K.B. and H. Jiang. 1997. Effects of plant growth regulators on tall fescue rooting and water use. J. Turfgrass Mgt. 2(2):13-27.

Perry, V.G. and H. Rhoades. 1982. The genus Belonolaimus, p. 144-149. In: R.D. Riggs (ed.). Nematology in the southern region of the United States. Univ. Ark. S. Coop. Ser. Bul. 276.

Trenholm, L.E., M.J. Schlossberg, G. Lee, W. Parks, and S.A. Geer. 2000. An evaluation of multispectral responses on selected turfgrass species. Int. J. Remote Sensing 21:709-721.

U.S. Golf Association. 1999. Water withdrawals, Use, Discharge, and Trends in Florida. 1995. USGA Water Resour. Investigation Rpt. 994002 .

Zhang, X. and R.E. Schmidt. 2000. Hormone-containing products impact on antioxidant status of tall fescue and creeping bentgrass subjected to drought. Crop Sci. 40:1344-1349.

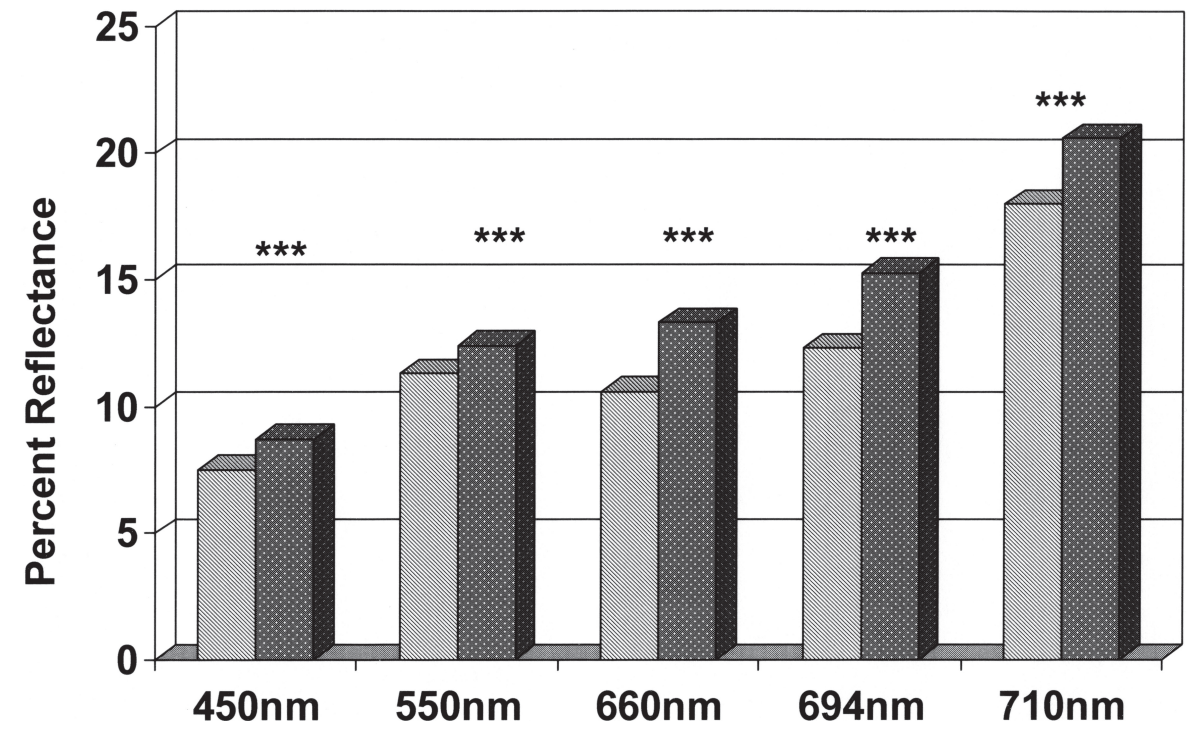

Fig. 9. Reflectance values of fairway bermudagrass after $14 \mathrm{~d}$ of no irrigation.

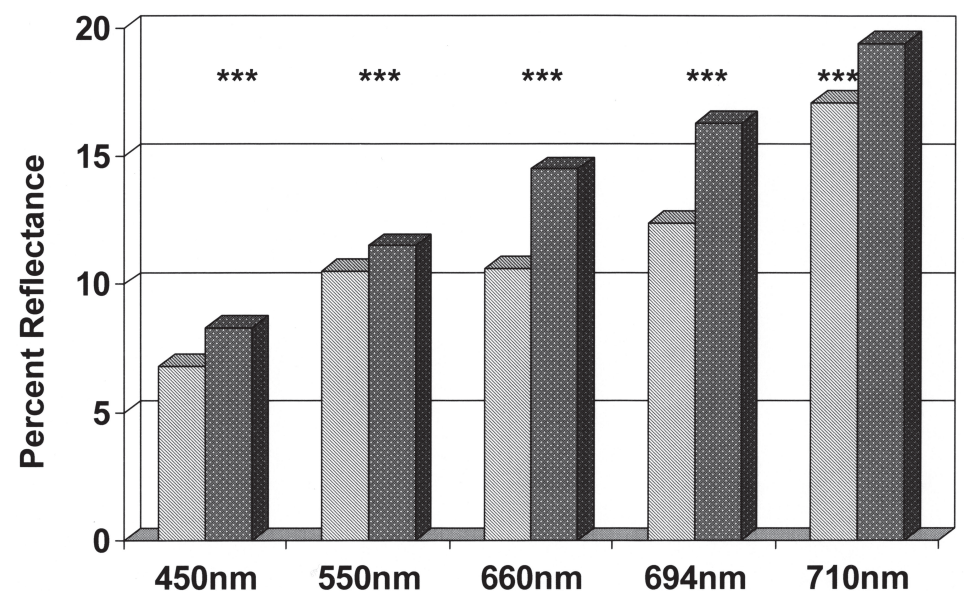

